This content is available online at AESA
e-ISSN: $2456-6632$

\title{
A lack of response of irrigated soybean (Glycine max L. Merr.) in rotation with cotton (Gossypium hirsutum L.) in the Mississippi Delta, USA
}

\author{
H. Arnold Bruns* (D), Krishna N. Reddy and William T. Pettigrew \\ Crop Production Systems Research Unit, USDA-ARS JWDSRC Box 350, Stoneville, MS 38776, USA \\ "Corresponding author's E-mail: arnold.bruns@ars.usda.gov
}

\section{ARTICLE HISTORY}

Received: 23 May 2018

Revised received: 02 August 2018

Accepted: 13 August 2018

\section{Keywords}

Cotton (Gossypium hirsutum L.)

Crop rotation

Crop yield

Soybean [Glycine max (L.) Merr.]

\begin{abstract}
The effects of cotton (Gossypium hirsutum L.): soybean [Glycine max (L.) Merr.] rotations on the respective crops are limited. This manuscript discusses the response of irrigated soybean in crop rotation with cotton. An irrigated soybean: cotton rotation experiment was conducted from the year 2012 through 2015 near Elizabeth, MS. The crop rotation sequences were included continuous soybean (SSSS), continuous cotton (CCCC), cotton followed by soybean (SCSC), soybean followed by cotton (CSCS), soybean followed by two year of cotton (SCCS), and cotton followed by two year of soybean (CSSC). The rotations were grown under two production systems conventional and transgenetic with respect to weed control. During this study, a weed control treatment of (pendimethalin pre-emergence vs. glyphosate postemergence) as included on the soybean plots was used. The soybean yields across rotations within a year were not significantly different. The means yields differed among years (3655.1, 3023.6, 3500.6 and 2600.3 Kg ha-1 for the year 2012, 2013, 2014 and 2015, respectively) and appear related to difference in rainfall/irrigation amounts. The results revealed that the weights of 100 seed samples averaged $13.9 \mathrm{~g}$ in the year 2015 which differed from the previous years (16.2, 15.6, and 16.2g; 2012, 2013 and 2014, respectively). Therefore, the rotations of cotton with soybean appear to have neither a beneficial or negative effect on soybean yield.
\end{abstract}

(C)2018 Agriculture and Environmental Science Academy

Citation of this article: Bruns, H.A., Reddy, K.N. and Pettigrew, W.T. (2018). A lack of response of irrigated soybean (Glycine max L. Merr.) in rotation with cotton (Gossypium hirsutum L.) in the Mississippi Delta, USA. Archives of Agriculture and Environmental Science, 3(3): 261-263, https://dx.doi.org/10.26832/24566632.2018.030308

\section{INTRODUCTION}

Crop rotations of many kinds have been practice worldwide for centuries and numerous scientific articles are available about rotations of various crop species (Bruns, 2012). However, for many years prior to the mid-1990's, continuous cotton production was a normal practice for much of the Cotton Belt of the United States because, even in rotation with other crops, the financial return per hectare would not match that of a monoculture of cotton and soybean (Hake et al., 1991; Ashworth et al., 2017). By the late 1990's changes in farm commodity support programs in the United States made the production of other crops besides cotton financially feasible. In the year 2001 several experiments on crop rotations with cotton begin to be published showing benefits from such practices. Wesley et al. (2001) compared deep soil tillage of heavy clay soils in autumn to conventional tillage in the Mississippi Delta. The rotation sequences with cotton and soybean increased yields of both crops when grown in combination with deep tillage. Guidy et al. (2001) reported data from a 10 year crop rotation study that a cotton-cotton-soybean rotation yielded economic returns above direct costs of $\$ 122.73$ (U.S.) and $\$ 327.03$ (U.S.) over continuous cotton and soybean respectively. Bryson et al. (2003) found a reduction in populations of the weed, purple nutsedge (Cyperus rotundus), in rotations of transgenic cotton and soybean. Using cotton, maize (Zea mays L.) and soybean in various rotation schemes, Ashworth et al. (2016) reported increasing crop diversity with these two crops in one or two 
years of a four year cycle with cotton stabilized cotton seed yield in the long-term. Pettigrew et al. (2016) recently reported from this experiment lint yield increases of cotton following soybean were likely a result of increased soil- $\mathrm{N}$ fixed by the previous soybean crop and/or altered microbial populations favorable to cotton. Potential rotations of these two species exist due to annual changes in markets for these commodities. Therefore the present investigation was conducted to study the response of irrigated soybean (Glycine max L. Merr.) in rotation with cotton (Gossypium hirsutum L.) in the Mississippi Delta, USA.

\section{MATERIALS AND METHODS}

The soybean: cotton rotation experiment was conducted from the year 2012 through 2015 on a Dundee silty loam (fine-silty, mixed active, thermic Typic Ochraqualf) site $1.0 \mathrm{~km}$ north of Elizabeth, MS and leased by the Crop Production Systems Research Unit of the USDA-ARS at Stoneville, MS as described by Pettigrew et al. (2016). Rotation sequences were; continuous soybean (SSSS), continuous cotton (CCCC), cotton followed by soybean (SCSC), soybean followed by cotton (CSCS), soybean followed by two year of cotton (SCCS), and cotton followed by two year of soybean (CSSC). The rotations were grown under two production systems conventional and transgenetic with respect to weed control. Both herbicide treatments were applied according to label recommendations along with cultivation at plant growth stage $\mathrm{R}_{1}$ (Hanway and Thompson, 1967).

Seven d prior to crop planting the entire experimental area was sprayed with $1.1 \mathrm{Kg}$ a.i. $\mathrm{ha}^{-1}$ of paraquat for early vegetation control. For both transgenic and conventional soybean management systems both $S$-metolachlor and pendimethalin at $1.1 \mathrm{Kg}$ a.i. ha ${ }^{-1}$ each were applied pre-emergence. In the transgenic management system $0.9 \mathrm{Kgs}$ a.i. $\mathrm{ha}^{-1}$ of glyphosate was applied approximately $28 \mathrm{~d}$ post emergence and again at $\mathrm{R}_{1}$. For the conventional management system $1.1 \mathrm{Kg}$ a.i. ha ${ }^{-1} \mathrm{~S}$-metolachlor plus $0.27 \mathrm{Kg}$ ai ha ${ }^{-1}$ fomesafen were applied $28 \mathrm{~d}$ post emergence followed by chlorimuron at $151 \mathrm{~g}$ a.i. $\mathrm{ha}^{-1}$ applied at $\mathrm{R}_{1}$.

Field preparation began with disking and forming $51 \mathrm{~cm}$ high ridges, spaced $102 \mathrm{~cm}$ apart. In late winter $67.2 \mathrm{Kg} \mathrm{K} \mathrm{ha}^{-1}$ as murate potash was applied with no other fertilizer application later. Rows were harrowed to form a seed bed approximately 12 " across each ridge. The cultivar used, was Dekalb brand DKR 4744 R2/S (Monsanto, St. Louis, MO). Though it was a glyphosate resistant cultivar, it was used in both the transgenic and conventional management systems. The seeding rate for soybean was 121,500 seeds $A^{-1}$ in twin-row spaced $25.0 \mathrm{~cm}$ apart with $102 \mathrm{~cm}$ between row pairs. An experimental unit was eight row pairs $21 \mathrm{~m}$ long. Seeding dates for both crops were 24 April, 30 April, 5 May and 30 April for the years 2012, 2013, 2014 and 2015, respectively. Two furrow irrigations of $25.0 \mathrm{~mm}$ ${ }^{-1}$ were applied in 2012, three in 2013, two in 2014 and four in 2015. Irrigation applications in this experiment were made primarily to meet water management requirements for cotton. The Paraquat was applied as a desiccant at $1.1 \mathrm{Kg}$ a.i. ha ${ }^{-1} 14$ days prior to harvest. Four center row pairs were machine harvested with a Kincaid 8X-P (Kincaid Equipment Mfg. Haven, KS) combine equipped with a Harvest Master weighing system (Juniper Systems, Logan, UT), sampled and seed weights accumulated. Data were analyzed using PROC MIXED of the SAS system (Cary, NC).

\section{RESULTS AND DISCUSSION}

The results of irrigated soybean seed yields in four rotation schemes with cotton in the Mississippi Delta over four years are given in Table 1. The results indicated that the herbicide treatments were found to have no impact on seed yields nor seed weights and therefore were combined in the analysis of rotation sequences. The statistical analysis of data on the seed yields in the years $2012>2014>2013>2015$ were noted insignificantly $(P \leq 0.05)$ different among different years (Table 1$)$. Additionally, the statistical analysis also indicated that within years, yields across rotation schemes were not significantly different. The mean yield differences between years are most likely related to the amount of available water each year by both rainfall and irrigation (Table 2). Cotton is known to benefit from some drought stress between irrigations and that excessive irrigation can result in more vegetative grow, shading of the lower canopy thus causing boll drop and reduced yields (Munk and Farah, 2017). Numerous research articles demonstrate that soybean yields decline with drought stress, especially during reproductive growth. Mean weights of 100 seed samples were similar to observations on seed yield. Moreover, no statistically significant differences were observed between rotation sequences within a given year.

Table 1. Irrigated soybean seed yields in four rotation schemes with cotton in the Mississippi Delta over four years.

\begin{tabular}{lcccc}
\hline Rotation & \multicolumn{4}{c}{ Yield $^{\dagger}\left(\mathrm{kg} \mathrm{ha}^{-1}\right)$} \\
\hline Scheme & 2012 & 2013 & 2014 & 2015 \\
SSSS & 3621.5 & 2976.5 & 3574.5 & 3714.5 \\
SCSC & 3735.8 & & 3467 & \\
SCCS & 3621.5 & & & 2515.9 \\
CSCS & & 3016.8 & & 2566.7 \\
CSSC & & 3084 & 3467 & \\
MEAN $^{\ddagger}$ & 3655.1 & 3023.6 & 3500.6 & 2600.3 \\
\hline
\end{tabular}

${ }^{\dagger}$ Means of 12 replications; ${ }^{\ddagger}$ Means of 12 replications and 3 rotation schemes, LSD $_{0.05}=100.8$.

Table 2. Total available water to a cotton: soybean rotation experiment near Elizabeth, MS during May to August.

\begin{tabular}{lcccc}
\hline \multirow{2}{*}{ Source } & \multicolumn{5}{c}{$\mathrm{mm} \mathrm{ha}^{-1}$} \\
\cline { 2 - 5 } & 2012 & 2013 & 2014 & 2015 \\
\hline Rainfall $^{\dagger}$ & 386.1 & 191.8 & 351.8 & 164.3 \\
Irrigation & 50.8 & 76.2 & 50.8 & 101.6 \\
TOTAL & 436.9 & 268.0 & 402.6 & 265.9 \\
\hline
\end{tabular}

${ }^{\dagger}$ Mississippi State University Extension Service (MSUES). 2016. Delta Agricultural Weather Center. Mississippi State University, Mississippi State, MS. (Source: http://www.deltaweather.msstate.edu accessed on 28 February, 2017). 
However, the mean 100 seed weights were 16.2, 15.6, 16.2 and $13.9 \mathrm{~g}$ for the year 2012, 2013, 2014 and 2015, respectively with the only significant $(P \leq 0.05)$ difference being the observed mean for 2015 being less than the three previous years. Again, the less available moisture in 2015 compared to the previous years' undoubtedly resulted in lower seed weight due to possible moisture stress that occurred. These data demonstrate that neither a benefit nor detrimental effect of rotating soybean with cotton will occur with respect to seed yield or seed weight in soybean regardless of the rotation scheme used in producing these two crops. As previously reported, cotton does appear to receive a yield benefit following soybean (Pettigrew et al., 2016) and though there does not appear to be any negative effect of cotton preceding soybean neither is there evidence of soybean yield increases following cotton based on data from this study. The potential increase in income with greater cotton lint yields combined with the lack of negative effects on soybean seed yields should justify the employment of rotations in producing these two crops.

\section{Conclusion}

The present investigation concluded that Soybean yields across rotations within a year were not significantly different. Means yields differed among years (3655.1, 3023.6, 3500.6, and $2600.3 \mathrm{Kg} \mathrm{ha}^{-1}$ for the years 2012, 2013, 2014 and 2015, respectively) and appear related to difference in rainfall/ irrigation amounts. Weights of 100 seed samples averaged 13.9 $\mathrm{g}$ in 2015 which differed from the previous years (16.2, 15.6, and 16.2g; 2012, 2013 and 2014, respectively). Thus, the rotations of cotton with soybean appear to have neither a beneficial or negative effect on the soybean yield. Wilhelm and Wortmann (2004) also reported the similar changes in the crop yield of corn and soybean due to the crop rotations.

\section{ACKNOWLEDGEMENT}

Trades names are used in this publication are solely for the purpose of providing specific information. Mention of a trade name, propriety product, or specific equipment does not constitute a guarantee or warranty by the USDA-ARS and does not imply approval of the named product to exclusion of other similar products. The author declares there is no conflict of interests regarding the publication of this article.

Conflict of interest: The authors have not declared any conflicts of interest for work or results or materials used in this manuscript.

Open Access: This is open access article distributed under the terms of the Creative Commons Attribution License, which permits unrestricted use, distribution, and reproduction in any medium, provided the original author(s) and the source are credited.

\section{REFERENCES}

Ashworth, A.J., Allen, F.L., Saxton, A.M. and Tyler, D.D. (2017). Impact of crop rotations and soil amendments on long-term no tilled soybean yield. Agronomy Journal, 109(3): 1-9, https:// www.mssoy.org/ uploads/ files/ ashworth-et-alagron-j-feb-2017.pdf

Ashworth, A.J., Allen, F.L., Saxton, A.M. and Tyler, D.D. (2016). Long term corn yield impacted by cropping rotations and bio-covers under no-tillage. Agronomy Journal, 108(4):14951502, https://doi.org/10.2134/agronj2015.0453

Bruns, H.A. (2012). Concepts in crop rotations. pp. 26-48. In: G. Aflapui (editor) Agriculture Science. InTech Publications. Rijeka, Croatia.

Bryson, C.T., Reddy, K.N. and Molin, W.T. (2003). Purple nutsedge (Cyperus rotundus) population dynamics in narrow row transgenic cotton (Gossypium hirsutum) and soybean (Glycine max) rotations. Weed tech. 17(4):805-810, https:// doi.org/10.1614/WT02-177

Guidy, K., Boquet, D.J. and Hutchinson, R.L. (2001). Profitability of cotton crop rotation systems in northeast Louisiana. LSU AgCenter. Retrieved from http://www.lsuagcenter. com/portals/ communications/ publications/ agmag/ archive/2001/ summer/ profitability-of-cotton-croprotation-systems-in-northeast-louisiana on 2 August, 2017.

Hake, K.D. Blasingame, Brumester, C., Goodell, P.B. and Stichler, C. (1991). Physiology today, National Cotton Council. Vol 3, No.1 Retrieved from https://www.cotton.org/tech/ physiology/cpt/soilmgt/upload/CPT-Oct91-REPOP.pdf

Munk, D. and Farah, H. (2017). Why schedule irrigation? p 7. In: C. Perryand E. Barnes. Eds. Cotton Irrigation Management for Humid Regions. Cotton Incorporated. Retrieved from https://www.cottoninc.com/wp-content/uploads/2017/03/ cotton-irrigation-schedule.pdf

Pettigrew, W.T., Bruns, H.A. and Reddy, K.N. (2016). Growth and agronomic performance of cotton when grown in rotation with soybean. Journal of Cotton Science, 20: 299-308, http:// journal.cotton.org

Hanway, J.J. and Thompson, H.E. (1967). How a soybean plant develops, Special Report 53, revised edition, lowa State University Cooperative Extension Service, Ames, lowa, USA, Retrieved from https://lib.dr.iastate.edu/ cgi/ view content. cgi? article $=1050 \&$ context $=$ special reports

Wesley, R.A., Elmore, C.D. and Spurlock, S.R. (2001). Deep tillage and crop rotation effects on cotton, soybean and grain sorghum on clayey soils. Agronomy Journal, 93(1): 170-178, https://doi.org/10.2134/agronj2001.931170x

Wilhelm, W.W. and Wortmann, C.S. (2004). Tillage and rotation interactions for corn and soybean grain yield as affected by precipitation and temperature. Agronomy Journal, 96: 425-432, https://doi.org/10.2134/agronj2004.0425 